\title{
The Effectiveness of Small and Micro Enterprises Government Support Programs in Case of East Gojjam zone, Ethiopia
}

\author{
Dirgu Getenet \\ Management department, Deber Markos University, Ethiopia
}

\begin{abstract}
The purpose of this study was to examine the effectiveness of small and micro enterprises government support programs. Government support program includes loan provision (youth revolving fund), market access, capacity building (training and technical assistance) and working premises. The research method was mainly explanatory. To collect primary data a self-administered questionnaire was distributed to 385 SMEs owner-mangers to examine the effectiveness of support services given by the government. 321 questionnaires properly filled and returned with $83 \%$ response rate. Data was analyzed using descriptive statistical tools. The result show that even if the government invested a huge amount of resources on support services/programs it did not achieve intended outcome because of bureaucracy;(a) to get youth revolving fund corruption and collateral requirement are an obstacle (b) working premises(lack of infrastructure: power, road and water, and location is not ease market accesses), incompetency (trainings are not fit with local and sectoral context).
\end{abstract}

Keywords: Small and Micro Enterprise, business development support, effectiveness

DOI: $10.7176 / \mathrm{EJBM} / 12-22-04$

Publication date:August $31^{\text {st }} 2020$

\section{Introduction}

The successful establishment of Small and micro enterprise (SME) and their subsequent evolution and development has long been the sources of interest and concern for researchers, government and policy makers because they are increasingly important to the economic growth of the given country. In response government have introduced a variety of policies and programs, including the provision of finance, advice, training, working premises to facilitate the formation and promotion SMEs.

Small and micro enterprise policies play a central role in economic development across Africa, but more effective, evidence-based policy evaluation is required to inform future interventions(Bernard A. Obeng and Blundel 2015). SMEs provide a unique contribution to regional employment and competitiveness.

Enterprise promotion is increasingly seen as a central strand in the new generation of economic development policies that are being introduced across Sub-Saharan Africa(Obeng and Blundel 2015). Public authorities throughout the world, recognizing both the importance and fragility of small and micro enterprises (SME), so over the years created agencies and set up numerous business development support and assistance measures and policies. Despite all these efforts, SME owner-managers do not appear to make maximum use of the services available(Audet and St-Jean 2007).

Developing country governments rarely evaluate their SME programs, but it performed in high income countries such as the U.S. and Europe (World Bank 2010). Study is necessary on which SME programs work, why, and how programs can be better designed and implemented to maximize economic benefits to firms and workers. Most developing countries continue to spend scarce resources on SME support programs, many of unsure value(OECD 2007). So, SMEs support service evaluation has benefits; it helps for measuring satisfaction with services provided or identifying areas of program, design and implementation for improvement.

The Government of Ethiopia has been committed to the development of the of small and micro enterprises sector as it is stipulated in the SME development strategy and other sectors' policies and strategies (Federal Democratic Republic of Ethiopia 2016).

Effectiveness of the SMEs support services: we mean Effectiveness" "Effectiveness" refers to the extent to which the delivery of services met the expectations of SMEs owner- mangers/, policy makers, small business and donors(Tuibeqa 2015).

\section{Problem statement}

The entrepreneurship issue in Ethiopia is as important for the reduction of poverty. One of the strategy developed by Ethiopian government in the growth and transformation plans (GTP I\&II) that will be implemented from 2011 -2020; for reducing poverty is the development of small and micro enterprises. Even if, the government has designed and implemented a national SME development strategy which facilitates the growth of the sector, but the sector continues to perform below expectations due to various challenges(Federal Democratic Republic of Ethiopia 2016).

Government of Ethiopia spends a large share of resources on small and micro enterprise programs each year, for example in 2017/18 these enterprises received more than Birr 8.6 billion in loans(National Bank of Ethiopia 
2019). How effective these programs have been in achieving their objectives is unclear, evaluation on effectiveness of small and micro enterprise support programs are rare in Ethiopia. Yet, there is little evidence of sustainability and growth despite resources being poured into operationalizing provider institutions and the maintenance of support programs.

Tuibeqa (2015), Smith and Stevens (2010), Gibb and Li (2003) identified the reasons for the failure of the SMEs support services and assistance programs includes First, there is a belief in government that successful support services and assistance programs of developed countries could be easily transferred to developing countries. There are socio-cultural conditions that are embedded in the entrepreneurial environment that influence the norms and values of support services and assistance program adaptation, this makes it difficult to transfer and adapt ideas across countries with different geographical, socio-cultural, economic and financial conditions. Second, the difficulty of fitting western entrepreneurship models into different cultural settings, third, there is a problem of deficiency in the knowledge and capacity of service providers to adapt new ways of doing things to replace the old systems and practices as they become obsolete, Finally, there is a mismatch between the needs of those seeking support services and the actual support offerings in the market.

Different researchers (Tuibeqa (2015),Smith and Stevens (2010), Gibb and Li (2003)) argue that SMEs support services and assistance programs must consider the heterogeneity of SMEs in terms of sector, size, level of growth and technological intensity, and the production and innovation system, and location in which they are embedded calls for specific and tailored efforts when providing support and assistance services. Notes that that although SMEs are supported in several ways across Africa, rigorous evaluation of such policies and their associated interventions is scant.

The Ethiopian SMEs development strategy that was revised in 2011 recognized the previous SME support programs was not effective because it was delivered similar services to all SMEs. The revised 2011 strategy introduced a support service that will be delivered based on the level of development i.e. start-up, growth and maturity levels. However different researchers argue in addition to the level, the support service must be customized based on sector /industry and geographical locations.

The aim of this study is to address issues by: documenting the most important gov't programs and other institutions who provide support and assistance service designed to promote small and micro enterprise; and critically examining those programs designed to promote entrepreneurship on various objectives. Through examining the response of owner-managers to a type of business support and assistance services that has been widely adopted or delivered. In this study the researchers try to address the following questions: (a)how did SME owner-mangers value the support services given to them? (b)what are the factors which determine the effectiveness of support services?

\section{SIGNIFICANCE OF THE STUDY}

This study focusses on the effectiveness of various supports services provided by government to small and micro enterprise. Thus, it is very important to evaluate the effectiveness the support offered for SMEs to identify the strength and weakness of the packages. Having a better understanding of small business owner-managers experiences and perceptions about the support services and assistance programs will lead to a more effective design and an appropriate delivery mechanism. Furthermore, it will lead to a more appropriate policy and strategic direction for those delivering the support assistance. The result of the study benefit different stakeholders like government support program designers, evaluators, policy-makers, resource planners and donor agencies to improve the delivery of small business support services

\section{Literature review}

Entrepreneurship development contributes to poverty reduction when it creates employment through the startup of new entrepreneurship or the expansion of existing ones and they increases social wealth by creating new markets, new industries, new technology, new institutional forms, new jobs and net increases in real productivity, increases income which culminates in higher standards of living for the population then it is logically to state that if the number of entrepreneurs of any given country increase the poverty indicators will decrease (Ali and Ali 2013). SMEs often lag behind larger firms in many dimensions of performance. This is widely believed to result from constraints SMEs face, including access to finance, weak managerial and workforce skills, inability to exploit scale economies in production, and imperfect information about market opportunities, new technologies and methods of work organization. In response, many high-income countries as well as developing countries have put in place a variety of programs offering financial products and subsidized business development services (BDS) to SMEs. BDS programs include skills development for workers, management training, technology upgrading, quality control and productivity improvement, market development, network formation and export promotion (World Bank 2010). 


\subsection{Ethiopia's SME Promotion Policy}

With a focus on achieving the five-year targets set for Growth and Transformation Plan (GTP I) and further strengthening the development of SMEs, the government revised the SME strategy in 2011 to address both the framework for providing support to SMEs and methods of implementation. In addition to strengthening the major points highlighted in the 1997 strategy, the 2011 revised strategy has made the following major improvements (FDRE, 2011).

In order to revitalize the sector, the 2011 revised strategy emphasizes human resource and technology development, market development, and finance or credit service support systems. Developing the entrepreneurial ability and technical, managerial, and marketing skills of SME operators through training was identified as the main area of human resource development support.

Generally, the current SME development policy and strategy as well as the attention it gets from the government and other development partners seem to be enabling. The majority of the problems encountered by SMEs emanate from failures to fully implement the strategy and support frameworks(Mulu, Abebe et al. 2018). Ethiopia has launched various bold initiatives and development policies and plans to spur economic growth. The role of SME's is indispensable in poverty reduction through employment generation. Cognizant of this, a national SMEs Development Strategy was first formulated in 1997. Ethiopia's SME Policy envisages not only reducing poverty in urban areas but also nurturing entrepreneurship and laying the foundation for industrial development. The strategy was revised in 2010/11 with renewed interests and more ambitious targets on employment and number of entrepreneurs and transition to medium size level(Assefa, Zerfu et al. 2014).

\subsection{Small and micro enterprise support and assistance programs}

Enterprise support services fall into three categories: (a) Business development services (BDS), which include a range of consulting services, training for workers, management and quality control practices, technology upgrading, market development and export promotion; (b) research and development (R\&D) programs to promote investments in $\mathrm{R} \& \mathrm{D}$, stimulate development and introduction of new products and production processes; and (c) financing programs, typically concessionary loans for working capital, debt restructuring, and financial incentives to promote investments(World Bank 2010).

According to(OCED 2010) there are two main issues regarding SME promotion: "issues on creating a conducive business environment for the growth of SMEs" and "internal issues within the SME sector". An overview of these issues follows.

\subsection{The rationale of evaluating SMEs support and assistance programs}

Evaluation refers to a process that seeks to determine as systematically and objectively as possible the relevance, efficiency and effectiveness of an activity in terms of its objectives, including the analysis of the implementation and administrative management of such activity"(OECD 2007). We mean Effectiveness" "Effectiveness" refers to the extent to which the delivery of services met the expectations of SMEs owner- mangers/, policy makers, small business and donors(Tuibeqa 2015).

Amha and Ageba (2006) claim that the public intervention encouraged SMEs to develop innovative business practices, and improve their human capital development process, Support to small and medium enterprises (SMEs) can improve their revenue and profits, their ability to create jobs, labor productivity and their ability to invest. However, without appropriate evaluation it is difficult to assure the above benefits reaped.

The principal reason for doing evaluation is to establish whether or not policy has contributed to correcting or ameliorating the problem it set out to resolve, to make informed decisions about the allocation of funds, to show the tax payer and business community whether the programme is a cost effective use of public funds, and to achieve continued improvement in the design and administration of programs(OECD 2007).

A core justification for SME and entrepreneurship policy is the presence of coordination failures and information asymmetries, which may limit SMEs' ability to contribute to economic and industrial development, innovation, job creation and social cohesion. SME and entrepreneurship support can come in various forms, including advice, training, and enhanced access to finance and can help both, the individual SME owner as well as the rest of society through positive spill-over benefits in terms of job and wealth creation, as well as economic growth. There is consequently substantial direct public expenditure on SME and entrepreneurship programs and many other policy measures, which target SMEs, have important indirect public finance implications through foregone tax revenue. 
Conceptual framework of the study
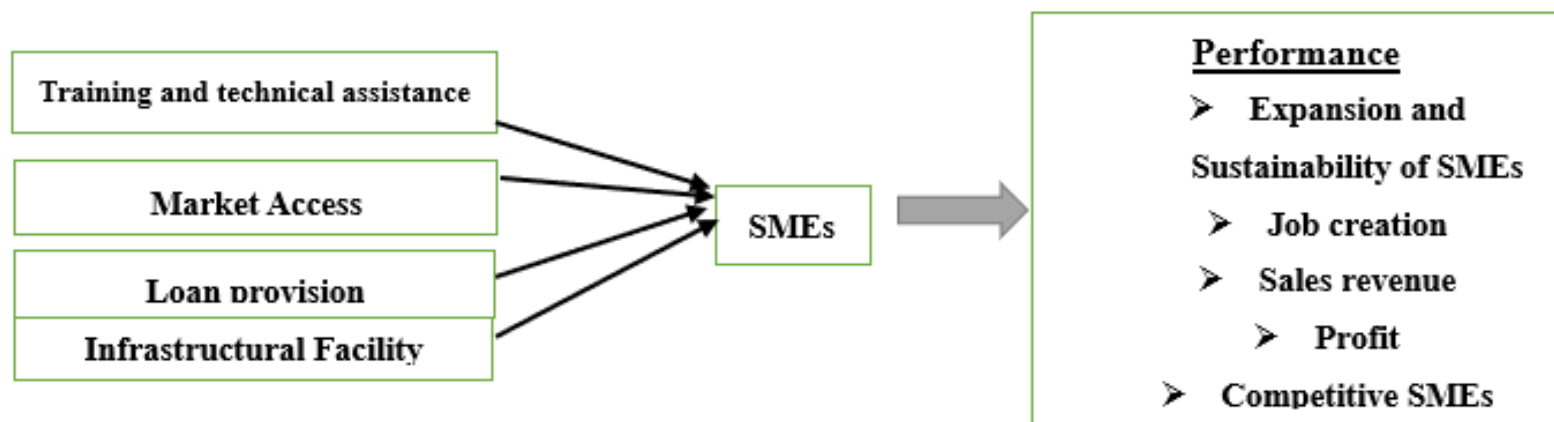

Source: (adopted from micro and small enterprise development strategy, Ethiopia 2011)

\section{Methodology}

The study used qualitative satisfaction survey of program beneficiary to assess policy effectiveness of programs. The process starts with a description of the enterprise support program(s) being evaluated. Among the support programs this study will focus on business development services (Training and technical assistance, Market Access, Loan provision, trainings, Infrastructural Facility (working premises)). This study utilized the survey research design. The study used survey data on SMEs which are targeted by government support.

5.1. Data type and collection method

Both primary and secondary data used to assess the effectiveness of SMEs support services/ programs for the promotion and development the sector. Primary data collected from owner or manager of the small and micro enterprises and from zonal/ district SMEs coordinators. Secondary data will be gathered from different sources i.e. books, journals, different published and un-published documents. The study used both questionnaire (survey method) and key informant interview. Questionnaire administered to a sample SMEs who get government supports or beneficiaries. The advantage of this approach is that surveys can be used to elicit different details about the respondent's program participation experience, satisfaction with support services provided.

\subsection{Sample size}

The Cochran formula allows you to calculate an ideal sample size given a desired level of precision, desired confidence level, and the estimated proportion of the attribute present in the population. Cochran's formula is considered especially appropriate in situations with large populations(Israel 1992). By using Cochran's formula for sample size determination, 385 selected. Multi stage sampling method employed. Stratified random sampling method used i.e. micro and small business who are engaged on the five sectors. The survey questionnaires were targeted at owner managers of the SMEs and in-depth interviews were aimed at officials work in institution who provide support to SMEs. 385 questionnaires distributed, 321 were properly filled and returned giving a response rate of $83 \%$.

\section{Results and discussion}

The Ethiopian government has implemented a variety of interventions to boost the promotion and contribution of the SME sector to the economy. The government support services to SMEs includes capacity building (training and technical assistance), market access, loan provision, infrastructural facility (working premises).

Access to Finance

Perhaps one of the major external challenges for SMEs in Ethiopia is the constraint to access loans. The startup capital to SMEs can be drawn from various sources, mainly from personal savings and family support, and loans obtained from financial facilities. $65 \%$ of owners/managers did not get or access to finance in any form given by government in the form of youth revolving fund, they respond that to access finance (a) difficult bureaucracy (b) corruption (c) collateral requirements are the major obstacles. The others $(35 \%)$ who had access to finance respond that the terms and conditions of loans become more restrictive over time particularly in terms of loan size and collateral requirements.

Market Access

Micro and small enterprises have the opportunity to sell their products only if suitable market accesses are provided. However, majority of $75 \%$ of owner managers respond that the current market access service is not effective to solve market problems. The current market access service are exhibitions during holidays and exclusive government contracts (for few sectors) all these did not solve market access problems. In Ethiopia market networking is an acute problem; most sell their products to the local market directly to the customer. Although the government provides exhibitions during holidays to enable the enterprises to display their products to the consumer, they are not effective since the exhibitions are usually held in very confined pedestrian walk ways and short period of time. Respondents believe that market accesses services are not create enough demand for their products and 
services.

Training and Capacity Building Programs

Technical Vocational Education and Training agency is a responsible government agency responsible managing the SMEs sector. The government through this agency provides numerous trainings for SMEs. Such trainings and capacity building programs are essential for the successful development of the enterprises. $73 \%$ of respondents (owner managers) had received different form of training on different areas, training in quality control, customer handling, bookkeeping, marketing and, entrepreneurship. such trainings increased sales and cost reduction. However, trainings given lack mostly localization to sector and locality. Although the trainings are given to most of the enterprises, their effectiveness and relevance is far from desired because of owners of the enterprises come from different social, educational and business backgrounds, some of them even having no educational or business background at all.

Infrastructural Facility (Production and Marketing Places)

Among the support services give to SMEs by the government is working premises (production and marketing places), only $23 \%$ of the owner-managers respond they get a working premise but it lacks utilities (road, power and water) and far from market access and the location and distribution of working premise are not balanced; most working premise are allocated for some sectors (manufacturing) and they are at outskirt of the town. Though the government provides production and selling places for many of the SMEs, a significant number of SMEs have to use either their home or rented premises as their production and marketing venue. Even the enterprises for which the government has provided production and marketing places are still not solving the sector problems. Access to infrastructure like transportation (road), water and power services, particularly in places located outside the town makes most working places (sheds) not preferred /used by SMEs.

\section{Conclusions}

Government of Ethiopia has developed plans and strategies and invested a lot of resources to promote, and ensure sustainability of SMEs. Lot of resources allocated in the form of support programs (loan provision, market accesses, capacity building trainings and working premises). From the above result we can conclude that even if the government invested a huge amount of resources on different support services it did not achieve intended outcome because of bureaucracy (to get youth revolving fund/finance and working premises), incompetency (trainings not fit with local and sectoral context). The government, along with all other stakeholders, should make every effort so that SMEs have access to finance, markets and working premises.

\section{References}

Ali, D. and A. Ali (2013). "Entrepreneurship development and poverty reduction: Empirical survey from Somalia." American International Journal of Social Science 2(3): 108-113.

Assefa, B., et al. (2014). "Identifying key success factors and constraints of Ethiopia's MSE development: An exploratory research." Addis Ababa: Ethiopian Development Research Institute.

Audet, J. and E. St-Jean (2007). "Factors affecting the use of public support services by SME owners: Evidence from a periphery region of Canada." Journal of Developmental Entrepreneurship 12(02): 165-180.

Bernard A. Obeng and R. K. Blundel (2015). "Evaluating Enterprise Policy Interventions in Africa: A Critical Review of Ghanaian Small Business Support Services." Journal of Small Business Management 53(2): 416.

Federal Democratic Republic of Ethiopia (2016). Growth and Transformation Plan II (GTP II). N. P. Commission. Addis Ababa.

Israel, G. D. (1992). Sampling the evidence of extension program impact, Citeseer.

Mulu, G., et al. (2018). Main Features of Micro and Small Manufacturing Enterprises in Ethiopia. Addis Ababa, Ethiopian development research institute (EDRI).

National Bank of Ethiopia (2019). The overall Economic Performance.

Obeng, B. A. and R. K. Blundel (2015). "Evaluating Enterprise Policy Interventions in A frica: A Critical Review of G hanaian Small Business Support Services." Journal of Small Business Management 53(2): 416-435.

OCED (2010). Key policy issues in entrepreneurship and sme development, organisation for economic cooperation and development,. PART II.

OECD (2007). OECD-framework-for-the-evaluation-of-SME-and-entrepreneurship-policies-and-programmes. Paris, Organisation for economic co-operation and development,.

Tuibeqa, A. T. (2015). A framework for small business support services in Pacific island countries based on experiential claims in Fiji, Victoria University.

World Bank (2010). Impact Evaluation of SME Programs in LAC. G. L. Acevedo and H. W. Tan. MEXICO, Poverty Reduction and Economic Management Sector Latin America and the Caribbean Reg. 